\title{
Instructional Case: When Derivatives Drive Earnings-Crown Oil, Inc.
}

Ahmed M. Ebrahim

Fairfield University, aebrahim@fairfield.edu

Sally Schultz

Joan Hollister

Follow this and additional works at: https://digitalcommons.fairfield.edu/business-facultypubs NOTICE: this is the author's version of a work that was accepted for publication in Journal of Accounting Education. Changes resulting from the publishing process, such as peer review, editing, corrections, structural formatting, and other quality control mechanisms may not be reflected in this document. Changes may have been made to this work since it was submitted for publication. A definitive version was subsequently published in Journal of Accounting Education, [23, 3-4, (Sept. 2010)] DOI: 10.1016/j.jaccedu.2011.07.001

\section{Repository Citation}

Ebrahim, Ahmed M.; Schultz, Sally; and Hollister, Joan, "Instructional Case: When Derivatives Drive Earnings-Crown Oil, Inc." (2010). Business Faculty Publications. 23.

https://digitalcommons.fairfield.edu/business-facultypubs/23

\section{Published Citation}

Ebrahim, Ahmed, Sally Schultz, and Joan Hollister. 2010. Instructional Case: When Derivatives Drive Earnings-Crown Oil, Inc. Journal of Accounting Education 28 (3-4) 198-209.

This item has been accepted for inclusion in DigitalCommons@Fairfield by an authorized administrator of DigitalCommons@Fairfield. It is brought to you by DigitalCommons@Fairfield with permission from the rightsholder(s) and is protected by copyright and/or related rights. You are free to use this item in any way that is permitted by the copyright and related rights legislation that applies to your use. For other uses, you need to obtain permission from the rights-holder(s) directly, unless additional rights are indicated by a Creative Commons license in the record and/or on the work itself. For more information, please contact digitalcommons@fairfield.edu. 


\title{
Instructional Case: When Derivatives Drive Earnings-Crown Oil, Inc.
}

\author{
Ahmed Ebrahim* \\ Charles F. Dolan School of Business \\ Fairfield University \\ Fairfield, CT 06824, USA \\ Email: aebrahim@fairfield.edu \\ Tel: +1 2032544000 ext. 2827 \\ Sally Schultz \\ School of Business \\ State University of New York at New Paltz \\ New Paltz, NY 12561, USA \\ Email: schultzs@newpaltz.edu \\ Tel: +1 845 257-2943 \\ Joan Hollister \\ School of Business \\ State University of New York at New Paltz \\ New Paltz, NY 12561, USA \\ Email: hollistj@newpaltz.edu \\ Tel: +1 845 257-2937
}

* Corresponding author 


\title{
Instructional Case: When Derivatives Drive Earnings-Crown Oil, Inc.
}

\author{
ABSTRACT \\ Crown Oil, Inc. is a family-owned heating oil distributor that offers customers the opportunity to \\ lock-in a fixed price per gallon in advance of the heating season by signing up for a price \\ protection plan. As a result of offering these plans, Crown Oil assumes the risk of price changes, \\ which it then hedges by acquiring exchange-traded future and option contracts. This case \\ provides an introduction to the economic nature of derivative instruments and hedging and to the \\ related accounting and reporting issues. The appropriate timing of revenue recognition for the \\ upfront fees that Crown Oil receives from customers entering into a price protection contract is \\ also explored in the case, as is the opportunity for earnings management. The case provides the \\ opportunity to research the professional accounting literature, apply existing standards, and \\ communicate recommendations to management
}

\section{Keywords:}

hedging

derivatives

hedge accounting

revenue recognition

earnings management 


\section{Introduction and economic background}

Crown Oil, Inc. (Crown Oil) is a family-owned heating oil distributor located in Portland, Maine. Crown Oil sells No. 2 heating oil at retail to residential and small business customers. Like others in the industry, Crown Oil uses derivative financial instruments to hedge its risk from changes in the price of heating oil. This case focuses on the financial accounting and reporting for Crown Oil's derivative transactions during 2008. Derivatives allow firms to hedge their business risks or speculate on market value changes. However, derivatives can create their own risks, and have led many firms (including Fannie Mae and Enron) to record large losses. Additional background information about derivative instruments and their treatment for financial accounting and reporting purposes is presented in Appendix A.

\subsection{Heating oil prices}

The cost of home heating oil—a winter necessity in the Northeastern US—began a rapid increase in 2000, after two decades of only moderate price variability. The graph in Figure 1 displays the average residential prices of heating oil in the State of Maine between 1980 and 2007. As in the other Northeastern states, prices hovered around $\$ 1.00$ per gallon (in nominal

dollar terms) during the 1980 s and 1990s. During the first decade of the $21^{\text {st }}$ century, however, the price of fuel oil tripled.

\section{Insert Figure-1 Here}

The cost of home heating oil is primarily dependent on the price of crude oil, which in turn is affected by worldwide supply and demand. At the beginning of the $21^{\text {st }}$ century, crude oil prices were influenced by geopolitical issues in oil-producing regions and market forces such as growing global demand, weather conditions, and falling crude oil inventories. Secondarily, the When Derivatives Drive Earnings: Crown Oil, Inc. 
cost of home heating oil is affected by seasonality in demand, local competition, and regional operating costs. In the short-run, weather can significantly affect price changes. For example, a cold snap affects both supply and demand: more fuel is needed at the same time as harbors and rivers are frozen and delivery systems interrupted (Energy Information Administration, 2008; Mergent Online, 2007).

\subsection{Hedging price volatility}

Given the volatility in oil prices during the first decade of the $21^{\text {st }}$ century, consumers welcomed the introduction of price protection plans by local retailers like Crown Oil. These plans allowed consumers to lock-in the cost of oil prior to the winter heating season, thus mitigating the risk of price increases. Such plans typically specified the price—or price rangeper gallon that customers would be charged, and the number of gallons under contract. Customers paid an initial signing fee at the time they entered into such a contract. The price protection plans essentially transferred the risk of oil price increases from the customer to the retailer. The retailer, in turn, could attempt to offset the risk assumed under price protection plans by investing in hedging instruments, such as exchange-traded future and option contracts.

\section{Crown Oil Company ${ }^{1}$}

Crown Oil is a family-owned S corporation, with patriarch Mark Klein serving as chairman and CEO. Mark's son David was the CFO, and a second son, William, managed the operating and marketing functions. The family has run the company successfully for decades, although David was the only one who had earned a business degree, and he did so in the years

\footnotetext{
${ }^{1}$ The case is based on a real situation of an existing company. However, all names, places, and numbers have been altered for confidentiality purposes.
} 
prior to the popularity of derivatives and their coverage in business school curricula. Crown Oil's fiscal year-end is October $31^{\text {st }}$, and the firm is audited by Paul Mallon, a local CPA who operates as a sole practitioner. The company's financial statements for the year ended October 31, 2007, appear in Appendix B.

\subsection{Crown Oil's price protection plans}

In recent years, many of Crown Oil's customers have taken advantage of the price protection plans it has offered. Starting in July, its customers may sign up for either a fixed-price or a capped-price contract covering deliveries during the coming heating season. The fixed-price contracts allow customers to lock in a specific price per gallon for deliveries, regardless of whether spot prices rise or fall. (Spot prices are those charged for immediate delivery.) These contracts obligate Crown Oil to deliver the number of gallons specified and bill the customer for the pre-established price per gallon. In order to lock-in the right to buy at this fixed price, customers pay an initial, nonrefundable fee of $\$ 0.25$ for each gallon covered by the contract. If a customer purchases more oil than specified in his or her contract, the price per gallon charged for the excess amount is the spot rate on the delivery date. On the other hand, if a customer fails to take delivery of the full quantity of oil specified in the contract, he or she is billed a penalty of $\$ 0.35$ for each undelivered gallon. So, although Crown Oil is obligated to deliver the number of gallons covered by a fixed- price contract at the agreed price, customers are not obligated to purchase the contracted amount, as long as they pay the penalty. If fuel prices drop substantially, 
a customer could buy heating oil at the spot price, pay the penalty to Crown Oil, and still incur a lower per gallon cost than under the fixed-price contract. ${ }^{2}$

In this case, we focus on Crown Oil's fixed-price contracts. However, the company also offers capped-price contracts to customers willing to pay a higher initial nonrefundable fee of $\$ 0.55$ per gallon. In exchange for this higher up front per gallon fee, the customer is charged the spot price on the delivery date whenever it is lower than the contracted price.

\subsection{Hedging the price-protection plans}

Crown Oil had adopted the practice of acquiring futures contracts traded on the New York Mercantile Exchange to try to hedge the risk it assumed under the price-protection plans. Each futures contract obligated Crown Oil to take delivery of 42,000 gallons (1,000 barrels) of heating oil at a specified futures price during the month the contract was to expire. The contract specified delivery of the oil in New York harbor. Crown Oil was located in Maine, and had no intention of actually taking physical delivery of the oil in New York. Instead, it closed its position using the net settlement feature provided by the exchange. Under the net settlement feature, if futures prices increased over time, Crown Oil would receive the difference between that price and the futures price specified in the contract. If futures prices decreased, Crown Oil would pay the difference between the current price and the contracted price. So, for example, if Crown Oil had entered into a futures contract to buy oil at $\$ 4$ per gallon, and the current price at the time the contract was terminated was $\$ 5$ per gallon, Crown Oil would receive the difference

${ }^{2}$ With a fixed price contract, the customer's total cost would be the sum of the $\$ 0.25$ contract fee times the number of contracted gallons, plus the fixed price for each gallon delivered up to the contracted amount, plus either the product of the spot rate times each gallon delivered in excess of the contracted amount, or $\$ 0.35$ times the number of undelivered contracted gallons. 
of $\$ 1$ per gallon. This cash inflow would offset the current $\$ 5$ cost to buy oil, resulting in a net cash outflow of $\$ 4$ per gallon for Crown Oil. If the price had instead fallen to $\$ 2.50$ per gallon, Crown Oil would have to pay the difference of $\$ 1.50$ per gallon to settle the contract, which combined with the current price of oil would again result in a net cash outflow of $\$ 4$ per gallon.

Crown Oil opted to hedge its risk using futures contracts because these did not require a material upfront cash payment under the terms of the firm's brokerage account. In contrast, acquiring options contracts would have required the payment of an initial premium, due to the one-sided nature of the agreement. The holder of an option to purchase heating oil at a contracted price has the right to exercise that option, but no obligation to do so. So, if the contracted price exceeded the current market price, the holder would simply let the option lapse. In 2008 the typical premium for a call option to purchase 42,000 gallons of fuel in the future at a strike (exercise) price equal to the spot price on the option purchase date was around $\$ 8,000$, or approximately $\$ 0.19$ per gallon. Using such a call option as the hedging instrument would result in a net purchase price per gallon of $\$ 0.19$ plus the lower of the option strike price, or the spot price on the delivery date. (Lower premiums were required for call options with strike prices higher than the spot price in effect on the contract purchase date. Likewise higher premiums were charged for call options with lower strike prices.)

\subsection{Transactions with hedging instruments}

The slow climb in oil prices during 2007 accelerated into a rapid upward trend during the first half of 2008, as shown in Figure 2. Not surprisingly, many of Crown Oil's customers entered into fixed-price contracts during the summer of 2008 to protect against the risk of further price increases. As of August 31, 2008, Crown Oil's customers had contracted for 9.2 million gallons of oil at a fixed price of $\$ 4.35$ per gallon, and an additional 4.2 million gallons at a cap 
price of $\$ 4.35$. As a result, Crown Oil collected a \$4,610,000 (9.2 Million x $\$ .25+4.2$ Million $x$ $\$ .55)$ in nonrefundable fees. The $\$ 4.35$ per gallon price had been established based on the assumption that fuel oil prices would continue to rise.

\section{Insert Figure-2 Here}

In early July, the future price for heating oil for heating oil distributors had been over $\$ 4.00$ per gallon, but by July 16 , it had declined to $\$ 3.84$ per gallon. David Klein, assuming that this was a temporary price decrease, arranged for 200 futures contracts at the $\$ 3.84$ per gallon price, timed to mature at various dates between November and April of the upcoming heating season. Towards the end of August, David realized that a total of about 319 future contracts would be required to hedge the entire 13.4 million gallons covered by customers' contracts. By this time, futures prices had further declined to $\$ 3.44$ per gallon; David decided to take advantage of what he estimated to be a low price for the year by entering into another 100 contracts to purchase oil at this price.

However, oil prices continued to drop, as Figure 2 illustrates. In fact, the decline in the price of oil was so great that David began to worry that a number of customers might terminate their fixed price agreements - paying the $\$ 0.35$ per gallon penalty (or breaching the contract). Some customers had already starting calling, asking to switch from fixed-price contracts to capped-price contracts, and the decision was made to honor these requests to maintain customer goodwill. CEO Mark Klein was concerned that the price of oil would continue to decline, and he advised David to cut their losses on the futures contracts. On September 26, David closed the 200 futures contracts acquired on July 16 by paying a net settlement amount of \$6,216,000 (200 contracts $\times 42,000$ gallons per contract $\times[\$ 3.10-3.84])$. Table 1 summarizes these transactions. 


\section{Insert Table-1 Here}

With the possibility of continued price decreases, the Kleins concluded that exchangetraded options might be a better choice of hedging instrument than the futures contracts. Although the purchase of call options would require payment of an initial premium, this was the maximum cost that the firm would incur. If prices continued to decline, Crown Oil would buy oil on the open market rather than exercise the options. However, if market prices were to increase above the options' strike price, Crown Oil would exercise its options to buy fuel at the lower price. Mark agreed that David should purchase 200 call options with a $\$ 3.10$ strike price, paying a total premium of $\$ 1,600,000$. These contracts protected Crown Oil from price increases on 8.4 million gallons. By October 31, 2008, the company's fiscal year-end, the strike price had fallen to $\$ 2.00$ per gallon, and as a result, the call options that had been purchased during September at $\$ 8,000$ per contract were now trading at $\$ 2,000$ each.

\subsection{Revenue and expense recognition}

Because Crown Oil had designated its future and option contracts as hedging instruments, Mark Klein anticipated that the losses on the derivatives would not be recognized in net income, but would be reported as an item of other comprehensive income for the fiscal year ended October 31, 2008. However, David thought the loss realized on the 200 futures contracts closed on September 26 might have to be reported in net income, and he agreed to raise the question with Mr. Mallon, the company's accountant.

The $\mathrm{CEO}$ and $\mathrm{CFO}$ were also debating how to account for the nonrefundable fees received from customers who had signed up for a price protection plan. These contracts had been negotiated before the end of the fiscal year (October 31, 2008), for oil deliveries that would take 
place between November and the following April—during the next fiscal year. Mark Klein thought that the fees should be deferred and recognized as revenue when the oil was delivered. But David argued that, since the fees were nonrefundable, they could be recognized as revenue for the current year, since technically the contracts were sold during the summer of 2008 . He noted that if the fees were recognized as revenue during the 2008 fiscal year, they would counteract some of the drag on earnings that would result from reporting the realized losses on the futures contracts that were closed, should the firm's accountant conclude that that was the appropriate treatment.

Contemplating the need for additional cash during the busy winter months, Mark and David Klein met with Ms. Baxter, an account manager at their bank. She expressed concern about how the recent decline in oil prices might affect Crown Oil's balance sheet and income statement. Ms. Baxter feared that if the firm reported another annual loss, the branch manager might be reluctant to renew or increase Crown Oil's credit line at the current interest rate. She suggested that the Kleins consult with their accountant to determine how best to mitigate the effects of the unexpected price swings on their 2008 financial statements.

\section{Requirements}

You have recently been hired as an intern by Paul Mallon, CPA, and he has just assigned you to the Crown Oil account. He asks you to review some questions that management has raised concerning the appropriate accounting for revenues from their price protection plans, and for the losses incurred on derivatives instruments acquired to hedge their risk from changing oil prices. (Review the material in the appendices to the case before considering responses to questions 2 through 5.) 
1. Crown Oil debits cash when nonrefundable fees are received from customers signing up for price protection plans - but what type of account (asset, liability, revenue, or expense) should be credited? Suggest two alternative ways to initially record the receipt of these fees, and identify arguments that could be cited in support of each of these choices. With reference to the accounting literature, which of these methods appear to have the most support?

2. Describe the concept of an economic hedge and identify several types of economic exposure that are frequently hedged. What is the objective of applying hedge accounting? Distinguish between a fair value hedge and a cash flow hedge.

3. What are the characteristics of a derivative financial instrument? For the futures and option contracts that Crown Oil entered into, identify the underlying and the units in which the notional amount would be expressed.

4. When Crown Oil acquired the futures and option contracts in the summer of 2008 to hedge its risk from changing oil prices, was it attempting to hedge an asset, a firm commitment, or a forecasted transaction? Identify a possible hedged item that would be representative of each category. FASB defined a firm commitment in the glossary in ASC 815-10-20: does Crown Oil's commitment appear to meet this definition? Describe how a firm commitment differs from a forecasted transaction, and give an example of each. Would you advise Crown Oil to designate the futures and option contracts as a hedge of an asset, a firm commitment, or a forecasted transaction?

5. Relate the designation of the hedged item as an asset, a firm commitment, or a forecasted transaction to the classification of the hedging instrument as a fair value hedge or a cash flow hedge. Explain how fair value hedges and cash flow hedges are accounted for. What are your recommendations concerning Crown Oil's treatment of the realized loss on the settlement of the 200 futures contracts, and for the losses on the derivatives still outstanding on the balance sheet date? What journal entries would you propose that Crown Oil record?

6. Draft a memo to the CFO of Crown Oil summarizing your recommendations related to the preparation of the financial statements for the year ended October 31, 2008. How should Crown Oil account for the contract signing fees received from customers, and for the futures and options contracts that had been acquired? How will your recommendations affect the 2008 financial statements? Discuss any opportunities for earnings management available to Crown's management for its fiscal years ended October 31, 2008 and 2009. 


\section{Appendix A - Hedging and derivatives: Basic concepts and accounting issues}

\section{Hedging}

Hedging is a form of risk management that typically involves taking a position in a financial instrument opposite to the exposure that results from an existing asset, liability, or future transaction. By betting against its original exposure, an entity can minimize the loss that would result from an undesirable outcome. Although a hedge can reduce potential losses, it can also reduce potential profits, and hedging instruments are often acquired by managers who lack a complete understanding of the range of possible outcomes that could result. Commonly hedged risks include those resulting from changes in the prices of assets, such as equity securities or commodities, and changes in interest rates or foreign exchange rates.

Some entities rely on natural hedges. For example, if a US firm holds a euro-denominated account receivable, it might hedge its exchange rate exposure by purchasing inventory on account at an invoice price denominated in euros. Then, if the euro weakens against the dollar, the loss on the account receivable will be at least partially offset by the gain on the account payable. On the other hand, if the euro strengthens, the account receivable will produce an exchange gain, which will be partially or fully offset by the loss on the euro denominated account payable. Other entities acquire derivative financial instruments as a means to hedge existing risks.

\section{Derivatives}

Derivatives are financial instruments that derive their value from the value of an underlying asset, rate, or index. For example, a stock option gives the holder the right to buy shares of stock at a set price, and thus eliminates the risk of changes in the price of the underlying equity security. The value of the option is derived from the value of the underlying 
stock: an option to buy stock at $\$ 40$ per share will be more valuable if the stock is currently selling for $\$ 45$ per share than if it is selling for $\$ 38$ per share. Derivatives may be used by producers and consumers to hedge the risk of loss from changes in the value of the underlying item, by speculators to profit from changes in the price of the underlying item, or by arbitrageurs to exploit price inefficiencies across different markets.

Financial instruments include cash, evidence of an ownership interest in an entity, or a contract that imposes a contractual obligation on one party and a contractual right to another party related to the transfer of cash or another financial instrument, or to the exchange of other financial instruments on potentially favorable or unfavorable terms (FASB Accounting Standards Codification (ASC) section 818-20-20; FASB, 2010, par. 8). Derivatives can be distinguished from traditional financial instruments (such as debt and equity securities) because they: (1) have one or more underlying items and one or more notional amounts or payment provisions; (2) require little or no investment at the inception of the contract; and (3) require or permit net settlement. An underlying may be any market-related variable, such as a specified interest rate or exchange rate, the price of a commodity or security, or an index of prices or rates (such as the consumer price index). A notional amount is a number of currency units, shares, pounds, bushels, or other units specified in the contract. The value of the derivative contract is determined by the interaction between the market price of the underlying and the notional amount. Net settlement implies that the parties need not actually exchange the underlying item, but can make the final settlement of any differences in cash. Note that a contract that involves something that the reporting entity expects to use or sell in the normal course of business (other than a financial instrument) represents a purchase or sale agreement rather than a derivative instrument. 
The four basic types of derivative instruments are forwards, futures, options, and swaps, which in combination can produce more complex derivatives. A forward contract obligates the holder to buy or sell a specific amount or value of the underlying asset, rate, or index at a specified price on a specified future date. A futures contract is simply a standardized, exchangetraded variant of the forward contract. Both counterparties to such a two-sided contract have the potential for gain or loss, with one party's gain representing the other party's loss. Which party comes out ahead is determined by the direction in which the price of the underlying moves. For example, suppose a farmer enters a forward contract agreeing to deliver 1,000 bushels of corn for $\$ 3,300$ in 60 days. If the current market (spot) price of corn is $\$ 3.40$ per bushel at the time of settlement, then the farmer will be worse off and the counterparty better off. However, if the spot price for corn on the settlement date is only $\$ 3.20$ per bushel, then the farmer will be better off and the counterparty worse off. So, although each party to the contract reduces one risk, it also acquires another risk.

An option contract, in contrast, provides the opportunity for gain without any risk of loss beyond the initial investment to purchase the contract. The option purchaser has the right—but no obligation - to buy or sell a specific amount of the underlying at an established price within a specified period of time. A swap contract results when the counterparties agree to exchange one stream of cash flows for another. For example, in an interest rate swap, fixed interest payments may be exchanged for interest payments that vary based on a market rate.

\section{Accounting rules in flux}

A derivative acquired for speculative purposes should be reported on the statement of financial position at fair value, with any unrealized gains or losses resulting from changes in fair value reported in net income. However, when a derivative is acquired for hedging purposes, it is 
logical to account for the gain or loss on the derivative (the hedging instrument) in a similar fashion to the loss or gain on the hedged item. Hedge accounting aims to achieve this result, thus faithfully representing the economic reason for the hedge.

During 2008, the time frame covered by the Crown Oil case, FASB Statement of Financial Accounting Standards No. 133, Accounting for Derivative Instruments and Hedging Activities, was the source of US GAAP. In 2009, that standard became section 815 of FASB's Accounting Standards Codification (ASC) at the point when that became the sole source of US GAAP. The following year, the FASB proposed limited changes to hedge accounting in an Exposure Draft, Accounting for Financial Instruments and Revisions to the Accounting for Derivative Instruments and Hedging Activities (FASB, 2010) and then the International Accounting Standards Board (IASB, 2010) proposed more extensive changes to the hedge accounting model in its Exposure Draft, Hedge Accounting. In response, the FASB (2011a) issued an Invitation to Comment: Selected Issues about Hedge Accounting, to assess its constituents' views on the IASB proposal. As this case is going to press, the FASB (2011b) has announced its plans to redeliberate its views on hedge accounting based on feedback received in response to the Invitation to Comment. As professional standards continue to evolve, the Crown Oil case provides an opportunity to examine some of the accounting issues confronted by standards setters.

Accountants have identified three types of hedging relationships (IASB, 2010, par. 21; FASB ASC section 815-20-05-2). A fair value hedge occurs when an entity is hedging its exposure to changes in the fair value of a recognized asset or liability or of an unrecognized firm commitment. A cash flow hedge results if an entity is hedging its exposure to variability in cash flows attributable to a particular risk associated with a recognized asset or liability (for example, 
future interest payments on variable rate debt) or with a highly probable forecast transaction. A final type of hedging relationship results from a hedge of a net investment in a foreign operation. To qualify for hedge accounting under the IASB ED (2010, par. 19), as well as under FASB's ASC section 815-20-25-3, an entity must formally designate a hedging relationship by identifying the hedging instrument, the hedged item, the nature of the risk being hedged, and the means of assessing the effectiveness of the hedge. A hedge is effective to the extent that it produces offsetting changes in fair values or cash flows during the term of the hedge for the risk being hedged.

The FASB specified in ASC section 815-25-35-1 that gains or losses on a hedging instrument designated as part of a qualifying fair value hedge be recognized in earnings. The hedged item would be carried at fair value on the balance sheet, and the gain or loss that resulted from restating its fair value would be recognized in current earnings. ASC section 815-30-35-3 provided that the effective portion of the gain or loss on a derivative instrument designated as a cash flow hedge be reported in other comprehensive income, while the ineffective portion would be reported in earnings. These gains and losses would remain on the balance sheet in accumulated other comprehensive income until the expected cash flow occurred, and would then be reported in net income during the same periods that the hedged transaction affects earnings.

However, in its exposure draft, the IASB (2010, par 26-28) proposed modifying the accounting for fair value hedges to make it similar to that used for cash flow hedges: gains and losses on both the hedged item and the hedging instrument (excluding the ineffective portion) would be reported in other comprehensive income. On the balance sheet, changes in the fair value of the hedged asset or liability would be reported as a separate line adjacent to the line on which the hedged item appears. For cash-flow hedges, the IASB (2010, par. 29-30) proposed 
reporting the effective portion of unrealized gains or losses on the hedging instrument in other comprehensive income and reporting any ineffective portion in earnings. The gains and losses reported in other comprehensive income would be closed to a cash flow hedge reserve and eventually be reclassified into earnings during periods when the hedged item affects net income. Any losses that are not expected to be matched or covered by the hedging instrument in the future would immediately be reclassified into earnings. 
Appendix B: Crown Oil, Inc. financial statements for the year-ended October 31, 2007

Crown Oil, Inc.

\section{Combined Statement of Loss and Retained Deficit}

For the Year Ended October 31, 2007

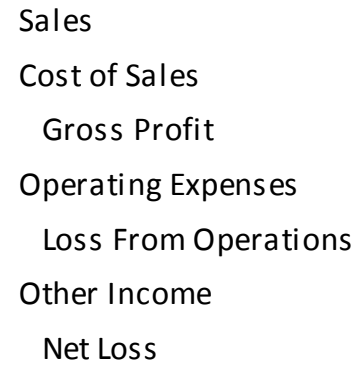

Crown Oil, Inc.

Statement of Comprehensive Loss

For the Year Ended October 31, 2007

Net Loss

Other Comprehensive Loss

Total Comprehensive Loss

Schedule of Accumulated Other Comprehensive Income (Loss)

Balance October 31, 2006

Unrealized Income (Loss) on Derivative Instruments:

Unrealized Holding Losses Arising During the Period

Reclassification Adjustment

Balance as of October 31, 2007

\begin{tabular}{cr}
$\$$ & $66,949,487$ \\
& $59,510,010$ \\
\hline$\$$ & $7,439,477$ \\
& $7,960,618$ \\
\hline$\$$ & $(521,141)$ \\
& 161,803 \\
\hline$\$$ & $(359,338)$ \\
& \\
\hline & $(700,372)$ \\
$\$$ & $(1,059,710)$
\end{tabular}




\section{Crown Oil, Inc.}

\section{Assets}

\section{Current Assets}

Cash and Cash Equivalents

$\$ \quad 4,957,663$

Short Term Investments

27,477

Accounts Receivable - Trade

$1,077,063$

Mortgage Receivable - Current Portion

46,529

Inventory

$3,457,470$

Prepaid Expenses

598,354

Total Current Assets

\begin{tabular}{cr} 
& 598,354 \\
\hline$\$$ & $10,164,556$ \\
& \\
$\$$ & $13,335,059$ \\
& $9,045,420$ \\
\hline$\$$ & $4,289,639$ \\
& \\
$\$$ & 15,000 \\
& 613,250 \\
& $1,273,108$ \\
\hline$\$$ & $1,901,358$ \\
\hline$\$$ & $16,355,553$ \\
\hline \hline
\end{tabular}

Liabilities and Stockholder's Equity

\section{Current Liabilities}

Trade Payables

\$ $1,133,736$

Customer Advances

$10,458,554$

Accrued Expenses and Taxes Payable

284,822

Current Portion of Long-term debt

554,572

Loans Payable

$1,353,244$

Total Current Liabilities

\section{Long Term Liabilities}

Security Deposit

Long-Term Debt - Less Current Portion

Total Long Term Liabilities

Total Liabilities

\section{Stockholder's Equity}

Capital Stock

$13,784,928$

Additional Paid-in-Capital

Retained Deficit

Accumulated Other Comprehensive Loss

Total Stockholder's Equity

Total Liabilities and Stockholder's Equity

\begin{tabular}{cr}
$\$$ & 10,333 \\
& $3,072,109$ \\
& $3,082,442$ \\
\hline$\$$ & $16,867,370$ \\
& \\
$\$$ & 125,885 \\
& $1,132,468$ \\
& $(1,059,710)$ \\
& $(710,460)$ \\
\hline$\$$ & $(511,817)$ \\
\hline$\$$ & $16,355,553$ \\
\hline
\end{tabular}




\section{Crown Oil, Inc. \\ Statement of Cash Flows \\ For the Year Ended October 31, 2007}

\section{Cash Flows From Operating Activities:}

Net Los

Adjustments to reconcile Net Loss to Net Cash

Provided by Operating Activities:

Depreciation and Amortization

(Increase) Decrease in Assets:

Accounts Receivable - Trade

$(157,089)$

Inventory

$(1,557,146)$

Prepaid Expenses

$(164,904)$

Security Deposit

(Increase) Decrease in Liabilities:

Accounts Payable-Trade

466,239

Customer Advances

$1,716,808$

Accrued Expenses and Taxes Payable

$(109,570)$

Net Cash Provided by Operating Activities

792,669

\section{Cash Flows From Investing Activities:}

Acquisition of Property, Plant, and Equipment

$\$ \quad(443,423)$

Net Decrease in Short Term Investments

855,017

Increase in Mortgage Receivable

Net Cash Provided by Investing Activities

$(408,389)$

\section{Cash Flows From Financing Activities:}

Increase in Loans Payable - Affiliates and Related Parties

$\$ \quad 514,498$

Long Term Debt

New Borrowings

534,115

Debt Reduction

$(572,829)$

$(650,000)$

Decrease in Subordinated Notes Payable to Stockholders

650,000

Increase in Additional Paid in Capital Net Cash Provided by Financing Activities

\begin{tabular}{rr}
\hline$\$$ & 475,784 \\
& \\
$\$$ & $1,271,658$ \\
& $3,686,005$ \\
\hline & $4,957,663$ \\
\hline \hline
\end{tabular}

Supplemental Disclosures

Interest Paid

$\$ 441,429$

Income Taxes Paid 
The following note regarding hedge accounting accompanied the financial statements:

\section{Note 2: Derivative Financial Instruments:}

The company uses derivative financial instruments to manage its exposure to market risk related to changes in the current and future market prices of certain petroleum product purchases. Believing it prudent to minimize the variability and price risk associated with the purchase of home heating oil, it's the Company's objective to hedge the cash flow variability associated with forecasted purchases of heating oil for resale through the use of derivative instruments when appropriate. To meet this objective, it's the Company's policy to enter into various types of derivative instruments to manage the variability of cash flows resulting from the price risk associated with forecasted purchases of home heating oil.

Beginning with the fiscal year ended October 31, 2003, the Company has adopted the provisions of SFAS No. 133 "Accounting for Derivative Instruments and Hedging Activities." SFAS No. 133 establishes accounting and reporting standards for derivative instruments and hedging activities. It requires the recognition of all derivative instruments as assets or liabilities in the Company's balance sheet and measurement of those instruments at fair value and requires that the Company formally document, designate, and assess the effectiveness and ineffectiveness of transactions that receive hedge accounting. Changes in the fair value of a derivative that is highly effective and that is designated and qualifies as a cash flow hedge are recorded in accumulated other comprehensive income until earnings are affected by the variability in cash flows of the designated hedged item.

For the year ended October 31, 2007, for derivative instruments designated as cash flow hedges, the Company reclassified the unrealized gain from derivative instruments of $\$ 495,169$ as of October 31, 2006 into earnings after the hedged forecasted transactions were exercised and affected cost of Sales for the year or expired during the year. The remaining Accumulated Other Comprehensive Loss of $\$ 710,460$ is related to derivative instruments outstanding at October 31, 2007, and this net amount is expected to be reclassified into earnings within the next eight months. 


\section{References}

Energy Information Administration. (2008). "Residential heating oil prices: What consumers should know," Brochure \#:DOE/EIA-X048, December 2008:

$<$ http://www.eia.doe.gov/bookshelf/brochures/heatingoil/index.html>

Financial Accounting Standards Board (FASB). (2009). ASC 815: Derivatives and Hedging. Norwalk, CT: Financial Accounting Foundation.

Financial Accounting Standards Board (FASB). (2010). Exposure Draft, Proposed Accounting Standards Update 1810-100 - Financial Instruments (Topic 825) and Derivatives and Hedging (Topic 815), Accounting for Financial Instruments and Revisions to the Accounting for Derivative Instruments and Hedging Activities. May 26, 2010. Norwalk, CT: Financial Accounting Foundation.

Financial Accounting Standards Board (FASB). (2011a). Discussion Paper-Invitation to CommentSelected Issues about Hedge Accounting, February 9, 2011. Norwalk, CT: Financial Accounting Foundation.

Financial Accounting Standards Board (FASB). (2011b). Accounting for Financial Instruments Summary of Decisions Reached to Date During Redeliberations: As of June 22, 2011. http://www.fasb.org/cs/BlobServer?blobcol=urldata\&blobtable=MungoBlobs\&blobkey=id\&blob where $=1175822693111 \&$ blobheader=application\%2Fpdf (accessed July 14, 2011).

International Accounting Standards Board (FASB). (2010). Exposure Draft (ED/2010/13), Hedge Accounting. London: IFRS Foundation (ISBN 978-1-907026-96-6).

Mergent Online. Industry Reports: Oil and Gas (November, 2007):

$<\underline{\text { http://www.mergentonline.com.libdatabase.newpaltz.edu/IndReports.asp?Type=View\&Page }=\text { fir }}$

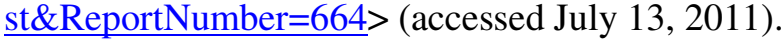




\section{Figure 1}

Average Annual Residential Heating Oil Prices in Maine 1980-2007

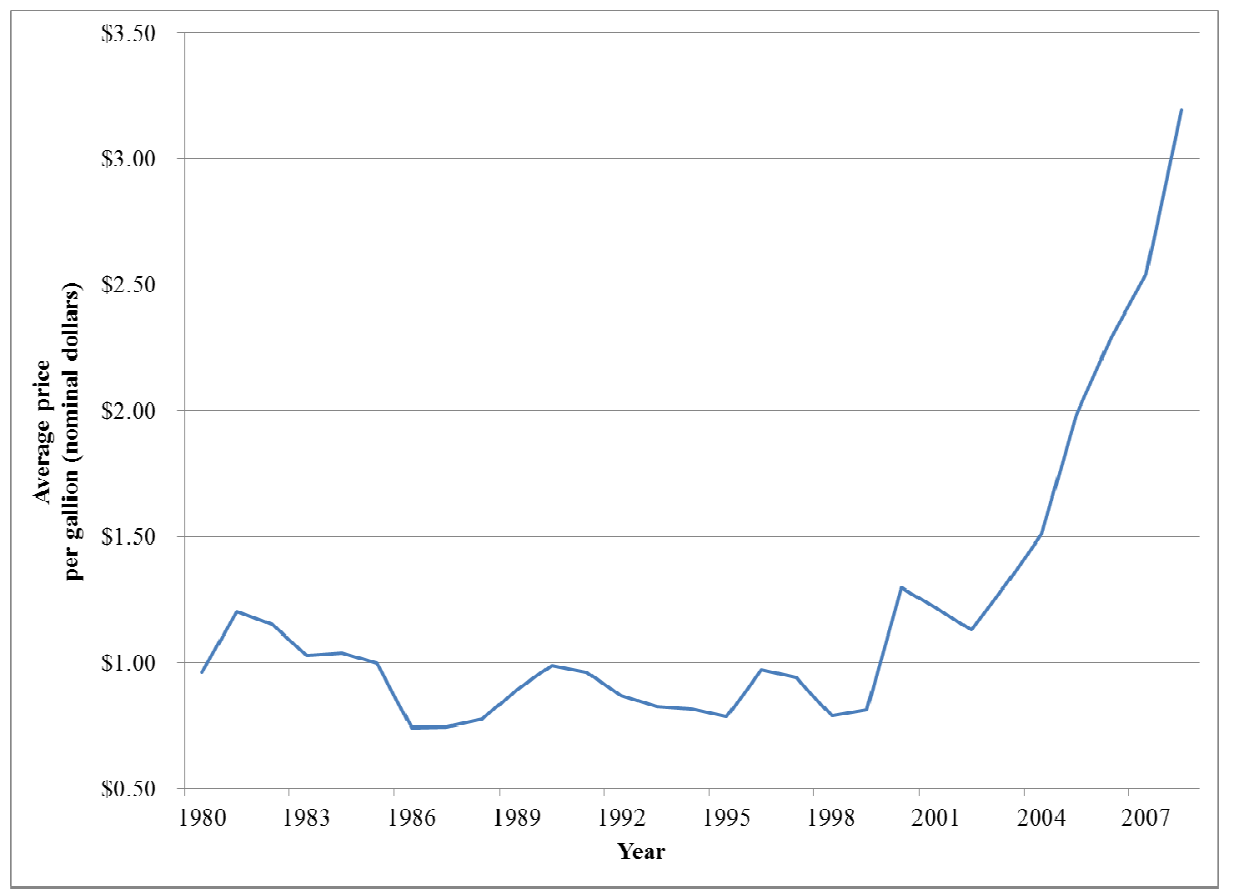

Adapted from data provided by the US Energy Information Administration: http://tonto.eia.doe.gov/dnav/pet/hist/d200111232a.htm 
Figure 2

Average Monthly Residential Heating Oil Prices in Maine 2007-2008

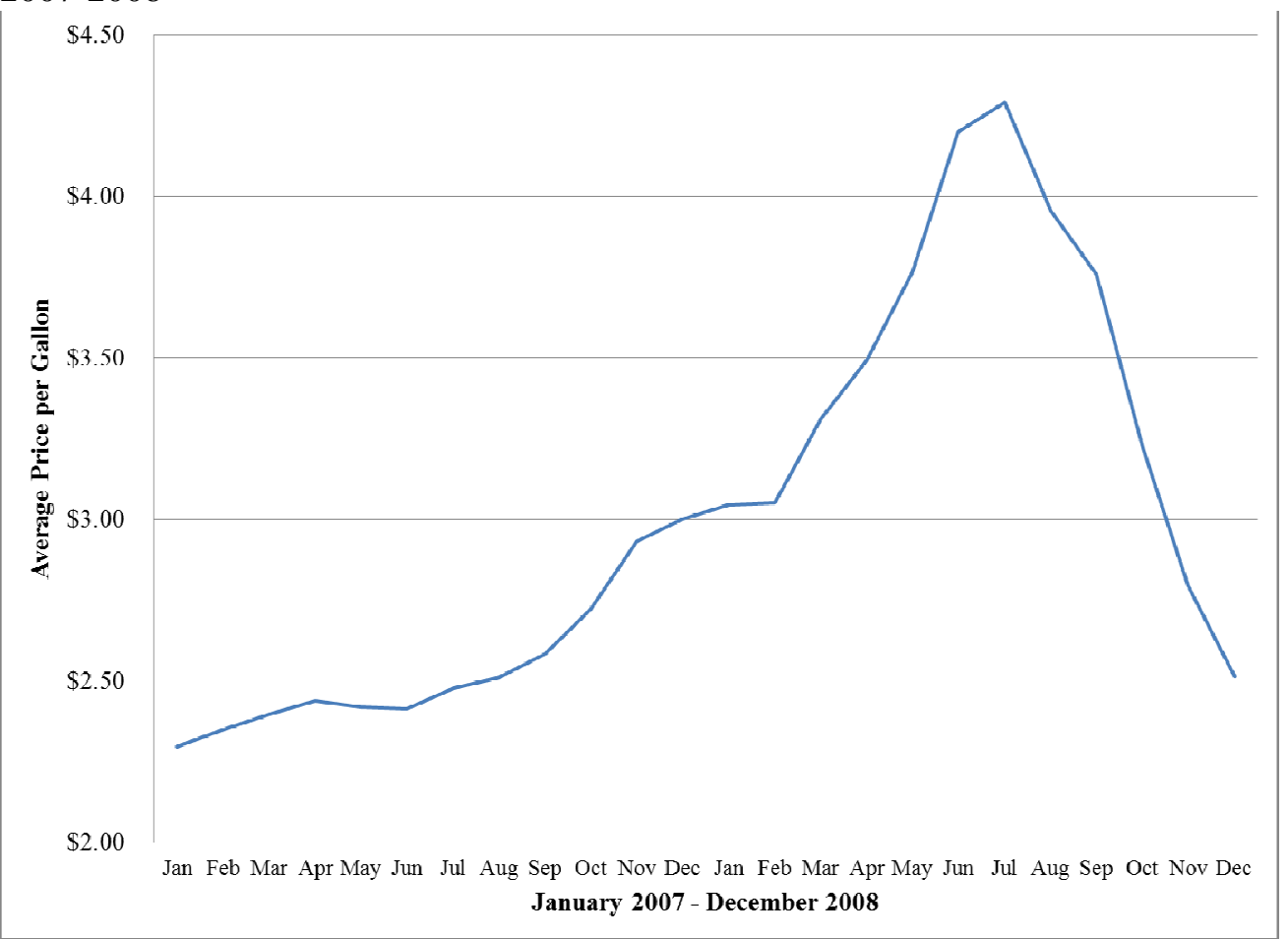

Adapted from data provided by the US Energy Information Administration:

http://tonto.eia.doe.gov/dnav/pet/hist/d200111232a.htm 
Table 1

Heating oil futures contracts entered into during 2008 by Crown Oil, Inc. (each contract covering 42,000 gallons)

\begin{tabular}{|l|l|c|}
\hline \multicolumn{1}{|c|}{ Date } & Contract transactions & Futures price per gallon \\
\hline July 16 & 200 contracts to purchase & $\$ 3.84$ \\
\hline August 20 & 100 contracts to purchase & $\$ 3.44$ \\
\hline September 26 & July 16 position closed & $\$ 3.10$ \\
\hline October 31 & & $\$ 2.00$ \\
\hline
\end{tabular}

